\title{
Modeling Reforestation's Role in Climate-Proofing Watersheds from Flooding and Soil Erosion
}

\author{
Robert L. France1, Andrew S. M. Patton1, Peter W. Aitchison ${ }^{2}$ \\ ${ }^{1}$ Department of Plant, Food and Environmental Science, Faculty of Agriculture, Dalhousie University, Halifax, Canada \\ ${ }^{2}$ Department of Applied Mathematics, University of Manitoba, Winnipeg, Canada \\ Email: rfrance@dal.ca
}

How to cite this paper: France, R.L., Patton, A.S.M. and Aitchison, P.W. (2019) Modeling Reforestation's Role in Climate-Proofing Watersheds from Flooding and Soil Erosion. American Journal of Climate Change, 8, 387-403.

https://doi.org/10.4236/ajcc.2019.83021

Received: July 22, 2019

Accepted: September 15, 2019

Published: September 18, 2019

Copyright $\odot 2019$ by author(s) and Scientific Research Publishing Inc. This work is licensed under the Creative Commons Attribution International License (CC BY 4.0).

http://creativecommons.org/licenses/by/4.0/

\begin{abstract}
The mitigation potential of reforestation for offsetting the deleterious effects of increased flooding and soil erosion projected to occur in Atlantic Canada through future climate change was investigated. Modelling determined a strong but non-linear relationship between extent of vegetative cover and runoff volume and discharge rate for a Nova Scotian watershed, suggesting that reforestation will reduce, but not completely prevent, flooding. Predicted erosion rates were found to be progressively reduced in relation to the extent of upland reforestation. Of three scenarios examined in which $60 \%, 65 \%$, and $85 \%$ of the entire watershed are randomly reforested, only the latter would reduce the elevated erosion expected to occur through climate change back to present-day existing levels. Additional modelling revealed that comparable mitigation of soil erosion can ensue through implementation of $70 \mathrm{~m}$ streamside buffer strips, which would only take up $19 \%$ of the total surface area. Prioritizing riparian zones for reforestation will therefore subsume less of the overall productive land area and therefore enact a less severe socio-economic impact on agriculture and forestry.
\end{abstract}

\section{Keywords}

Climate Change, Watersheds, Modeling, Flooding, Soil Erosion, Reforestation

\section{Introduction}

Changes in land use patterns [1], in particular widespread reforestation [2], have been suggested as a low-cost means to mitigate deleterious effects of global climate change. On the localized scale, climate change-induced alterations in ru- 
noff and erosion can be affected by the extent of vegetative cover [3] [4]. In particular, adaptive resilience to the ecohydrological impacts of climate change through the restoration of large portions of catchments [5] is one strategy of "climate-smart reforestation" [6] that might possibly be employed to "climate-proof" watersheds. The purpose of the present study was to expand upon previous work [7] [8] indicating a strong interdependence of hydrology and land-use for a small, predominantly rural watershed in Nova Scotia, Canada that has been the subject of extensive study [9] [10] [11] [12]. In particular, our interest was in using predictive modeling to determine the extent to which watershed reforestation might be capable of mitigating increases in watershed flow and consequent flooding and soil erosion that are projected to occur in the region due to future climate change [13].

\section{Study Area}

The Atlantic Canadian province of Nova Scotia is a region the Canadian Regional Climate Model (CRCM) [14] [15] predicts will experience increased precipitation throughout the $21^{\text {st }}$ century [16] [17]. Our climate and landscape modification models were applied to the North and Salmon Rivers watershed at the head of the Bay of Fundy in Colchester County, Nova Scotia (see regional maps in France et al. [8]). The combined watershed area is $740 \mathrm{~km}^{2}$ [10], of which 35\% had been deforested by the year 2000 (see land use map in France et al. [8]). The watershed has a shallow gradient, with only a $310 \mathrm{~m}$ difference in elevation along the $30 \mathrm{~km}$ length of its stream network. Local topography is also gentle, with riparian and upland slopes being less than 15\%. Until about a quarter of a century ago, forests accounted for $80 \%$ of the land cover in the watershed, dominated by softwoods (spruces and firs), followed by hardwoods (maples), and mixed stands [18]. Since then, the extent of forest cover has decreased (Figure 1), with only $60 \%$ of the total land area now being sylvan ( $\mathrm{T}$. O'Brien, Nova Scotia Department of Lands and Forestry, pers. comm.), coincident with a reciprocal increase in the extent of agricultural land in the mid and lower watershed (now 30\% surface area) and urbanization (now 10\% surface area) in the lower watershed (see representative landscape photos in France et al. [8]), as well as continued clearcutting in the mid and upper watershed. As shown in the upper map in Figure 1, the majority of the watershed in 1985 was still forested, as indicated by the light and dark green and yellow colours for different types of vegetative cover, whereas the red and pink respectively designate complete and partial removal of trees due to urbanization and peri-urban agriculture (centred around the city of Truro-Bible Hill in the southwestern terminal reaches of the watershed) and a patchwork of isolated clearcuts scattered throughout the middle and upper reaches of the watershed (Compare this map to that of land use conditions for the watershed in the year 2000 displayed in Figure 3 in France et al. [8].) As shown in the lower map in Figure 1, over the next two decades much of the watershed's forests had disappeared. This was predominantly 


\section{Forest Cover - 1985}

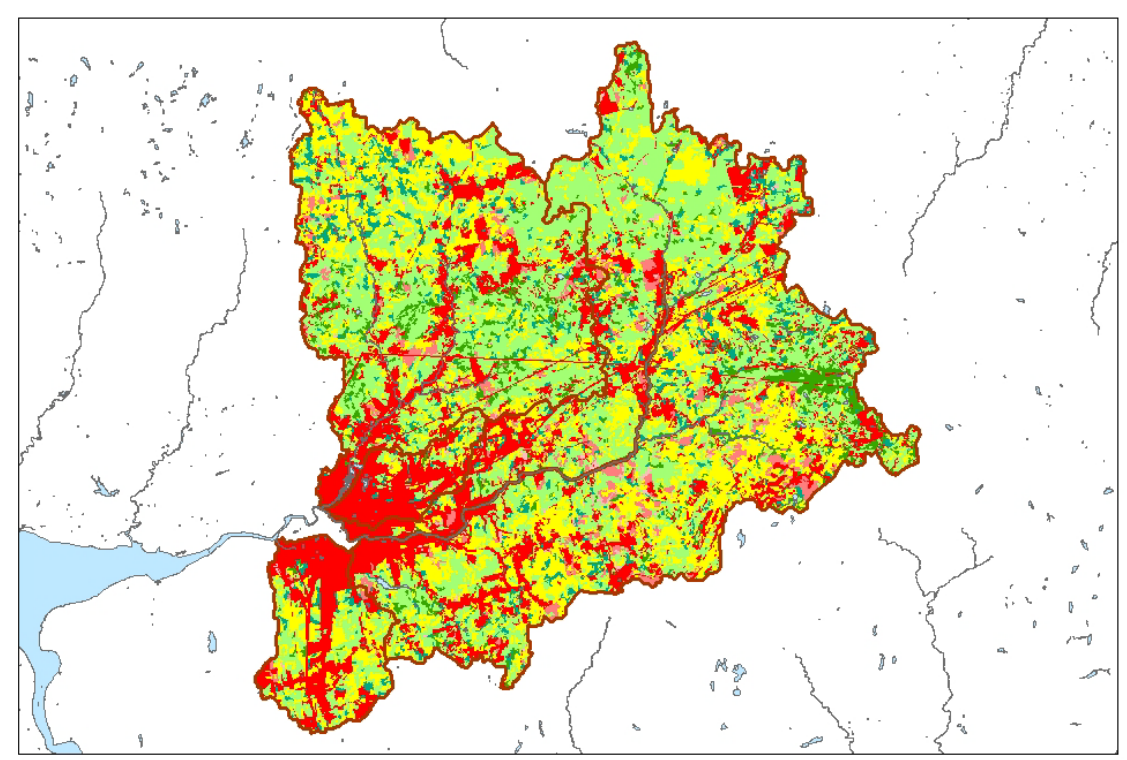

\section{Change in Forest Cover} $1985-2004$

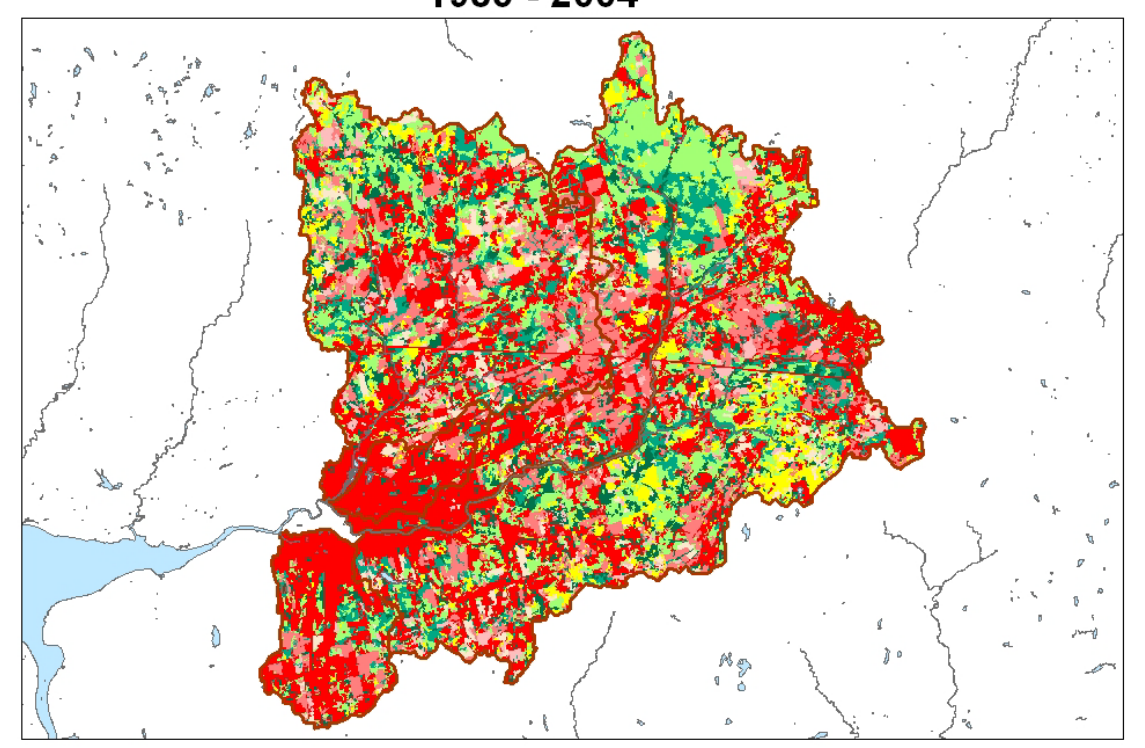

Figure 1. Changes in land-use, in particular, forest cover, in the combined North and Salmon Rivers watershed in Nova Scotia (T. O'Brien, Nova Scotia Department of Lands and Forestry). Linear distance from headwaters to outlet at the Bay of Fundy is $30 \mathrm{~km}$ for scale.

due to agricultural intensification, secondarily through a result of urban development, and finally in consequence of some further clearcutting.

The watershed was selected for the present investigation of the modeled interplay between climate and land use change due to it being the subject of previous study in terms of its hydrology [7] [10], (and more than a dozen government "gray literature" reports cited therein) and soil properties and erosion [8] [18]. The watershed is considered to be representative of small, coastal watersheds in 
Atlantic Canada that experience flooding and threatened water quality [11].

The North and Salmon Rivers conjoin and discharge into the Bay of Fundy by running through the coastal cities of Truro and Bible Hill (which have a combined population of about twenty thousand). The joint urban centre lies on the floodplain that, previous to drainage by seventeenth-century Acadian settlers from Europe, had been a tidal saltmarsh. The first serious flood was recorded in 1792 , and the frequency of such events has increased dramatically in recent years [12], including 2003, 2005, 2012, 2016, and 2017. Much of this threat is a consequence of poorly planned residential development that has progressively encroached upon the floodplain (in contrast, many original buildings constructed in the nineteenth and early twentieth centuries were built upon small rises of higher ground). Today, more than two thousand people and six hundred buildings and up to $\$ 43$ million dollars in infrastructure are estimated to be at risk due to flooding in the North and Salmon Rivers watershed, a condition caused not only by increased downstream flow but also occasionally from impeding ice jams as well as tidal storm surges moving upstream (A. McKinnon, City of Truro Public Works Dept., pers. comm.). The result has been a legacy of flooding studies, many recommending various mitigation measures, with major investigations being undertaken in the years 1917, 1938, 1947, 1952, 1969, 1971 (twice), 1974 (twice), 1977, 1978, 1979, 1980 (twice), 1981, 1988, 1997, 1998, 2002, 2004, before Patton conducted his own study in 2005. The most recent report [12] proposed the implementation of a suite of flood protection measures, both structural and non-structural, to be necessary for Truro-Bible Hill.

\section{Methods}

\subsection{Watershed Runoff and Discharge Rate}

The influence of variable land use on flooding in the combined North and Salmon Rivers watershed was determined through use of a GIS application of the Natural Resources and Conservation Service (NRCS) methodology, based on soil drainage, runoff curve numbers, TR-55 techniques, and data manipulation to simulate three patterns of vegetative cover: Scenario 1-land use conditions of the watershed as they existed in the year 2000, with 35\% being deforested; Scenario 2-the hypothetical worst possible land use condition, with all mature forests being clear-cut (i.e. 97\% deforested); and Scenario 3-the hypothetical best possible land use condition, wherein all clearcut areas are reforested and allowed to grow into maturity such that only $15 \%$ of the watershed remains without vegetative cover.

Since the 1950s, the CN or curve number method has become one of the most popular tools for calculating runoff depths due to its simplicity, flexibility, and versatility [7]. By providing a way to estimate the amount of stormwater runoff from information provided on site conditions and the amount of rainfall from a given storm, the $\mathrm{CN}$ method is able to show the effect of land-use change on runoff. The standard CN approach [19] was therefore used to calculate runoff 
volume for a 1:20 year rainfall event (103 $\mathrm{mm}, 24-\mathrm{hr}$ duration) estimated for the area by Environment Canada [9] for the three scenarios of varying vegetative cover. GIS data on watersheds [20], land use [21] and soils [22] generated CN values for polygons, to which an Antecedent Moisture Condition of III [23] was applied, based on the drainage ability of soils [24]. Higher values of $\mathrm{CN}$ correspond to higher volumes of runoff.

We modeled the effects of deforestation and reforestation on runoff volume and discharge rate by changing the $\mathrm{CN}$ values for each scenario. Runoff volume for Scenario 1 was calculated using four land-use categories: agriculture, clearcut, urban, and forest. Runoff volume for Scenario 2 was then calculated by changing the forest $\mathrm{CN}$ values to those for clearcut; whereas runoff volume for Scenario 3 was reciprocally calculated by changing the clearcut $\mathrm{CN}$ values to those for forest. Each change in $\mathrm{CN}$ values resulted in the derivation of a new runoff depth for each polygon. To determine the volume of runoff from each polygon for the simulated storm event, the runoff depth calculated by the curve number method was multiplied by the area of the polygon, with the total watershed runoff volume for each scenario being the sum of all those site-specific values.

The influence of watershed vegetative cover on discharge rate was determined through use of the NRCS TR-55 method, which calculates the peak discharge of a river following extreme storm events, by creating synthetic hydrographs [19] for the three scenarios. Land-use categories and $\mathrm{CN}$ values from the runoff volume calculations were used to derive a weighted $\mathrm{CN}$ value, integrated for the entire watershed, based, as before, on individual polygons, for each scenario of vegetative cover. In addition to the weighted $\mathrm{CN}$ value, the NRCS program required 11 other GIS parameters obtained using the "EcoViewer" program for Nova Scotia [22]. These were: rainfall depth, storm duration and distribution, watershed area, channel flow length and elevation change, overland flow length and elevation change, rainfall output time increment, and runoff time increment. To verify that appropriate $\mathrm{CN}$ values were chosen and that the modeling produced reliable results, the TR-55 program was used to model a recorded runoff event from a $72.4 \mathrm{~mm}$ rainfall on 28 and 29 April 1982 [25]. This allowed the synthetic runoff hydrographs to be compared to actual flow data for a station in the lower part of the watershed during this runoff event.

\subsection{Watershed Soil Erosion}

Previously, France et al. [8] examined the influence of climate change and best management practices on soil erosion in relation to runoff volume in the North River subwatershed. This was accomplished through use of a spatially-explicit model based on the Revised Universal Soil Loss Equation (RUSLE), as adapted to the North River subwatershed. The model, a standard employed in innumerable hydrological studies, relies on data of rainfall, soil erodibility, slope length and steepness, and cover management [26] [27]. The climatic factor (R) refers to the mean annual summation of individual storm erosion index values and is re- 
lated to the total kinetic energy in a maximum 30 min rainfall intensity [28]. Decadal-long patterns of monthly rainfall data from four local Environment Canada meteorological stations were used to create an $\mathrm{R}$ factor map for the subwatershed, with erosion rates grouped into three categories characteristic of Atlantic Canada [29] [30]: 11 - 22 tons $\cdot \mathrm{ha}^{-1} \cdot \mathrm{yr}^{-1}$ (Moderate), 22 - 33 tons $\cdot \mathrm{ha}^{-1} \cdot \mathrm{yr}^{-1}$ (High), and 33 - 44 tons $\cdot \mathrm{ha}^{-1} \cdot \mathrm{yr}^{-1}$ (Severe). Soil erodibility was derived from regional soil surveys [18] [29], and slope parameters were obtained through DEM analysis, as described in detail in France et al. [8]. Land-use cover was determined from the Nova Scotia data sources mentioned previously. The existing areal extent of soil erosivity for the watershed was determined to be $56.4 \%$, $42.7 \%$, and $0.9 \%$ of the subwatershed surface area for the respective categories of Moderate, High, and Severe. Projected changes in precipitation amounts, and therefore predicted potential soil erosivity, were obtained from the Canadian Regional Climate Change Model (CRCM) [14] [15], as applied to Nova Scotia, and as used for a nearby watershed. In particular, for the North River subwatershed, the estimated influence of regional climate change (i.e. increased precipitation) on soil erosivity was assessed by running the integrated (GIS, RUSLE) model with a $25 \%$ increase in the $\mathrm{R}$ factor projected for the region to end of the $21^{\text {st }}$ century [13].

For the present study, we built upon this earlier work by creating four scenarios to determine the role of watershed reforestation on soil erosion based on the three modeled levels of vegetative cover described above in addition to a fourth scenario based on the more recent (i.e. 2015) value of $40 \%$ being deforested, all run for the climate change projection of a $25 \%$ increase in precipitation for the last quarter of the $21^{\text {st }}$ century [13]. First, we empirically established the legal requirement of $30 \mathrm{~m}$ buffer strip widths around the network of streams in the North River subwatershed, determining that this subsumed 9\% of the surface area of the watershed (see Figure 12 in France et al. [8]). Next, our modelling was then directed toward understanding the effects of reforesting the non-riparian, upland areas to make up the remaining percentages of reforestation for each of the vegetative cover scenarios: the original Scenarios 1 and 3, and the new Scenario 4 . The model was run 20 times, each iteration randomly ascribing the remaining subwatershed areal reforestation to upland areas distant from the streams as follows: percentages of $56 \%$ (i.e. $65 \%$ forested surface area minus the $9 \%$ surface area for forested riparian buffers) for year 2000 Scenario 1, 76\% (i.e. $85 \%$ forested surface area minus $9 \%$ surface area for buffers) for the best case Scenario 3, and $51 \%$ (i.e. $60 \%$ forested surface area minus $9 \%$ surface area for buffers) for year 2015 Scenario 4,. The model was also run 20 times for Scenario 2 , randomly ascribing the vestigial $3 \%$ forested surface area left in the subwatershed to both riparian and upland regions combined. Mean values of subwatershed erosion were derived, with variability about those means in all four cases being less than $5 \%$. This is a result of the subwatershed's general conformity in terms of its topography; i.e. having a gentle overall gradient, with much of the upland areas being of low elevation with shallow slopes, and the absence of any 
significant dramatic landscape features such as steep hills or deep valleys (see Figure 10 in France et al. [8]). The goal was to determine how upland reforestation of the watershed might be able to mitigate the elevated soil erosivity projected for this watershed [8] in consequence of increases in precipitation and watershed flow predicted for the region [13].

\section{Results and Discussion}

\subsection{Influence of Climate Change and Land-Use on Flooding}

Given the predictions of increased watershed flow for this region of $9 \%$ to $25 \%$ to the end of the century in consequence of climate change [13] [17], city planning and public works infrastructure in Atlantic Canadian municipalities such as Truro-Bible Hill, where serious flooding is already a concern, will have to adapt. This is especially true given that the region is exposed and susceptible to extreme weather events (Figure 2); i.e. 17 hurricanes and major storms made landfall in

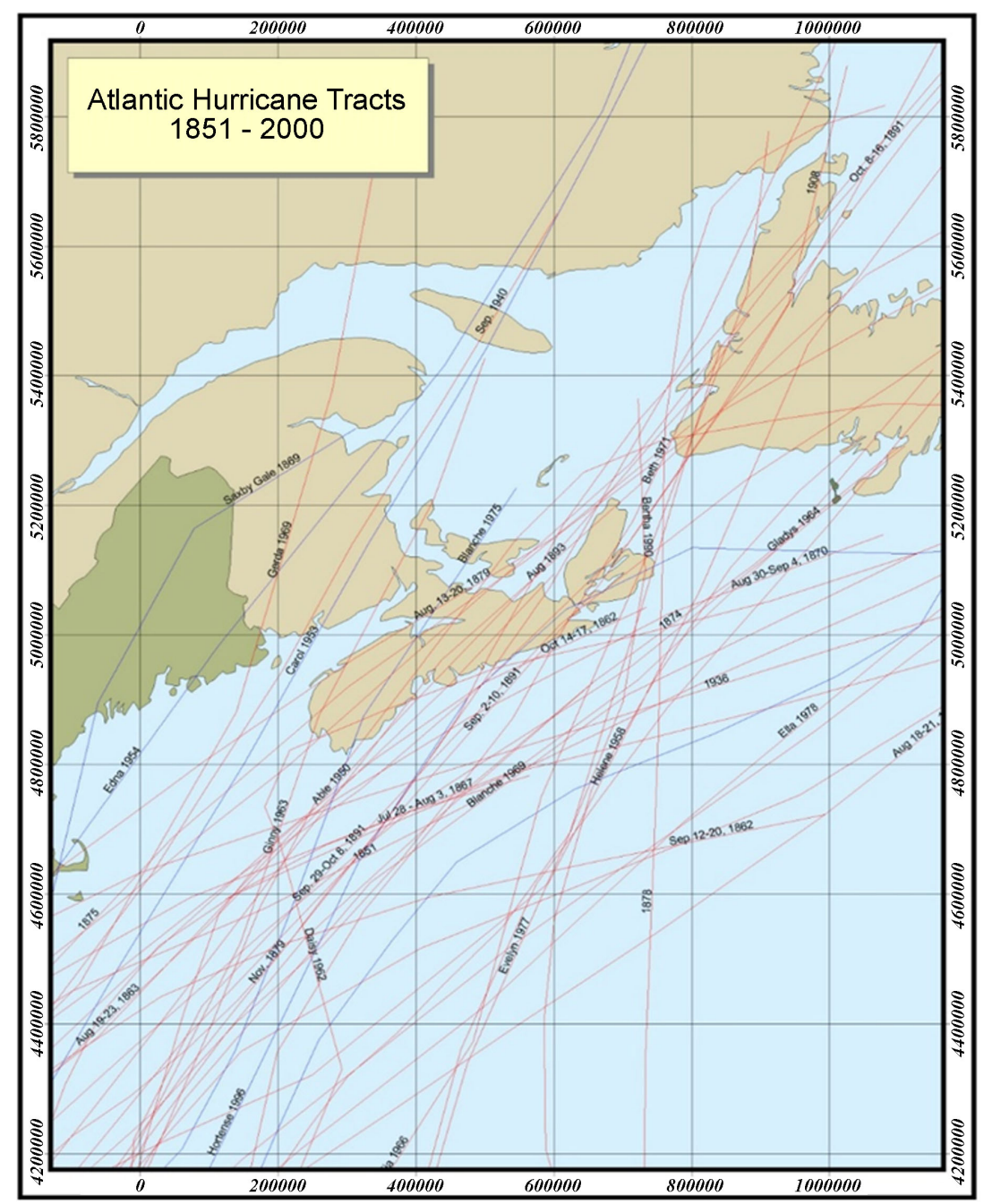

Figure 2. Historic hurricane and major storm tracks through Atlantic Canada [16], showing the locational susceptibility of the Bay of Fundy-discharging watersheds to extreme weather events. 
Nova Scotia between 1970 and 2005 [16]. Nevertheless, building within climatically-threatened floodplains, which in the case of Truro has, against all common logic, actually increased following large flooding events [12], must be called out for what it is: egregiously short-sighted watershed development [31]. Previous recommendations that hydro-engineering best management practices (BMPs), such as retention dams and storage reservoirs, be constructed in headwater regions of the North and Salmon Rivers watershed [7], will need to be seriously considered. The question examined in the present modeling exercise is whether the alternate "natural" BMP of reforesting substantial portions of the watershed can play a mitigating role on the severity of flooding expected to ensue through climate change.

Calibration test program runs for the rainfall event on 28 and 29 April 1982 found strong concordance between the hydrographs determined from direct monitoring of the storm and those generated synthetically. This gives credence to the reality of the CN and TR-55 model for the North and Salmon Rivers watershed. We found that changes in the extent of vegetative cover were predicted to exert a dramatic influence on the runoff volume and discharge rate (Figure 3 and Figure 4). Changing land-use conditions from those of the year 2000 (Scenario 1) to near complete removal of mature forests (Scenario 2), would increase runoff volume by $22 \%$ and maximum instantaneous rate of discharge by $23 \%$. This would certainly significantly increase the potential for flooding, and suggests that restricting forest clearance in the watershed-which primarily occurs

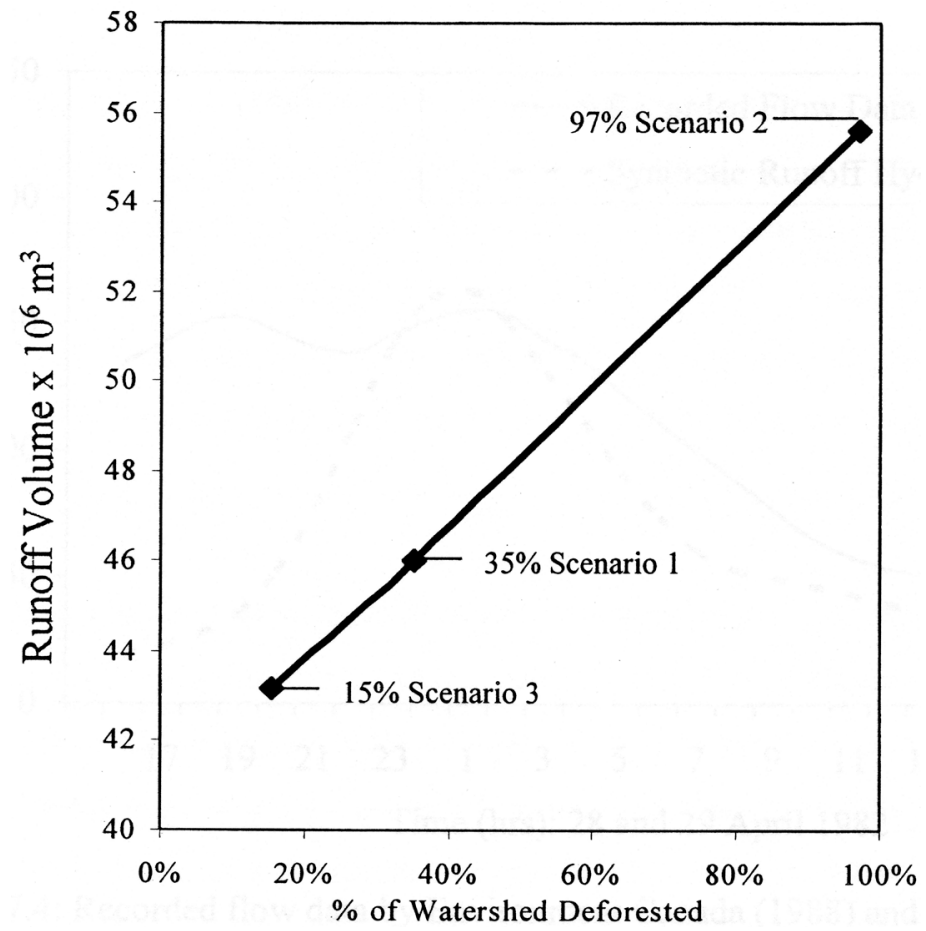

Figure 3. Relationship between extent of forest cover and runoff volume in the combined North and Salmon Rivers watershed, as calculated from the CN and TR-55 model described in the text. 


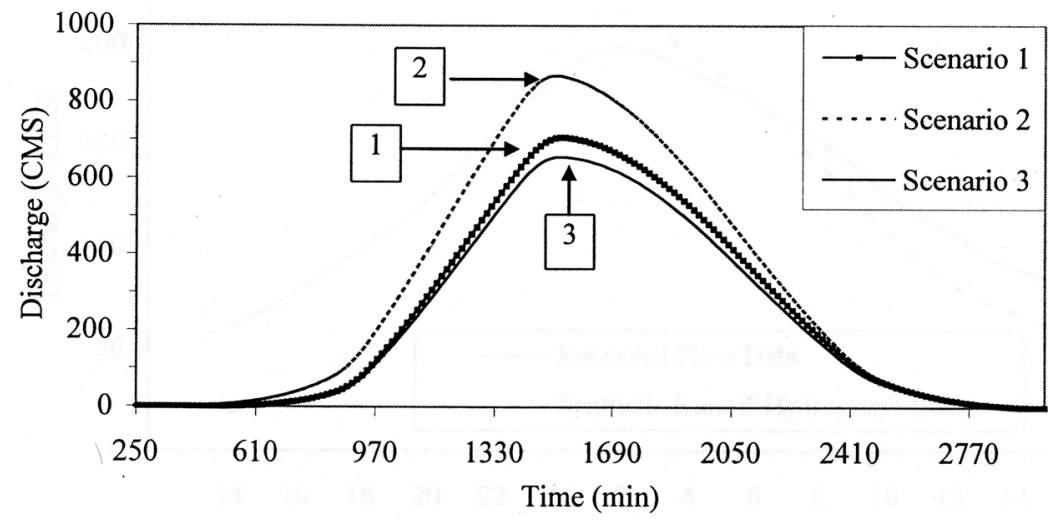

Figure 4. Synthetic hydrographs showing discharge rates at a site in lower Truro produced by the TR-55 program for each scenario of forest cover for the combined North and Salmon Rivers watershed. The peaks of the runoff hydrographs are maximum instantaneous discharges for each scenario in Figure 3.

for purposes of agriculture-may have to be considered. In other words, if deforestation on a large scale in this watershed is allowed to continue, it is likely that future flooding events in central Colchester County will become more severe.

There is a large literature indicating that forest clearcutting, such as that practiced on the scale in the sub-boreal regions of Canada [32] [33], leads to elevations in water export from watersheds [34] [35]. The increase in discharge rate and volume of runoff shown in our model for the North and South Rivers watershed is in agreement and was the result of altered $\mathrm{CN}$ values among the different scenarios. This is to be expected given the higher interception rates of rainfall by mature trees and leaf litter [36] [37], which together regulate both the amount and speed at which water moves across the land [38]. The present work therefore gives credence to Kindervater's [39] conclusion that heavy rainfall or rapid snowmelt can often be the primary causes of flooding in Nova Scotia. CBCL [12], however, tangentially mention (i.e. no data are provided) that some of their modeling implied that clearcutting in the North and Salmon Rivers watershed would not necessarily lead to major increases in the areal extent of flooding in Truro since during extreme rainfall events the ground quickly becomes saturated and therefore contributes to flooding regardless of forest cover. However, the report does contend that smaller rainfall events over clearcut areas would indeed produce higher runoff than before as a result of reductions in the amount of infiltration. It is important to realize that the predominant form of precipitation in the region is through events of smaller magnitude [40], and that other modeling does predict a $16 \%$ increase in intensity of such short period storms from historical 1980s values to the 2080s. Therefore, given regional projections of increases in the number of annual rainy days from the historical value 138 in the 1980s, to 151 in the 2020s, 154 in the 2050s, and 157 in the 2080s [16] [17], forest cover is expected play a dramatic role in regulating discharge arising from these high-frequency, small-amount events. The implication is obvious: con- 
temporaneous changes in vegetative cover will affect ecohydrology, soil erosion, and consequent nutrient enrichment of waterbodies [8]. The management question concerns whether reforestation can be an effective strategy to counter these effects.

\subsection{Mitigation of Flooding and Erosion by Reforestation}

Working the vegetative cover model in reverse for the combined North and Salmon Rivers watershed shows that if clearcut areas were replanted from 2000 levels (Scenario 1) and allowed to grow to a mature forest cover (Scenario 3), thereby reducing the deforested area by $20 \%$, then the runoff volume would be expected to decrease by $7 \%$ and maximum instantaneous discharge would decrease by $8 \%$ (Figure 3 and Figure 4). In other words, there is not a simple 1:1 linear correspondence for this watershed between the areal cover of forests and the geospatially-integrated volume of runoff or rate of discharge. These results suggest, therefore, that completely replanting clearcut areas in the North and Salmon Rivers watershed will likely minimize but will not completely prevent flooding. The implications for Atlantic Canadian watersheds are that management programs of upland reforestation could be one mitigation strategy to partially offset the expected increases in flooding due to forecasted climate change, but that there will be limits to the ultimate effectiveness of such a strategy. Other approaches such as construction of detention reservoirs and restriction of floodplain development will be necessary to ensure future protection against flooding from extreme weather events [7] [12].

Our spatially-explicit modelling for the North River subwatershed showed that implementing reforestation beyond a standard and generally accepted $30 \mathrm{~m}$ riparian buffer strip would exert a dramatic influence on soil erosion. Estimated erosion rates were found to be progressively reduced in relation to increases in the areal amounts watershed reforested, as outlined in the four scenarios (Figure 5). Importantly, only under the auspices of the best case of Scenario 3, in which $85 \%$ of the subwatershed is reforested (the maximum areal amount physically possible given existing urban development; i.e. $9 \%$ riparian $+76 \%$ upland forests), would the erosion rate (18.1 tons $\left.\cdot \mathrm{ha}^{-1} \cdot \mathrm{yr}^{-1}\right)$ be reduced from the forecasted elevated level due to climate change ( 26.1 tons $\cdot \mathrm{ha}^{-1} \cdot \mathrm{yr}^{-1}$; designated as " $\mathrm{C} \mathrm{C}$ " in Figure 5) to values that are below the present-day existing value of 20.9 tons $\cdot \mathrm{ha}^{-1} \cdot \mathrm{yr}^{-1}$ determined by France et al. [8] (designated as "Ex" in Figure 5). Lesser degrees of reforestation, as for example, $65 \%$ total watershed forested (i.e. $9 \%$ riparian $+56 \%$ upland forests) for Scenario 1; $3 \%$ watershed forested (i.e. $3 \%$ riparian and upland forests combined) for Scenario 2; and 60\% total watershed forested (i.e. $9 \%$ riparian $+51 \%$ upland forests) for Scenario 4 , still remained higher than the present-day existing value.

The act of "climate-proofing" water resources need not be restricted to policy [41] or economic [42] adaptations; rather, implementation of in- or on-the-ground physical BMPs are also important options to consider. Reforestation as a watershed management strategy to reduce erosion has been recognized and championed 


\section{Watershed erosion rate}

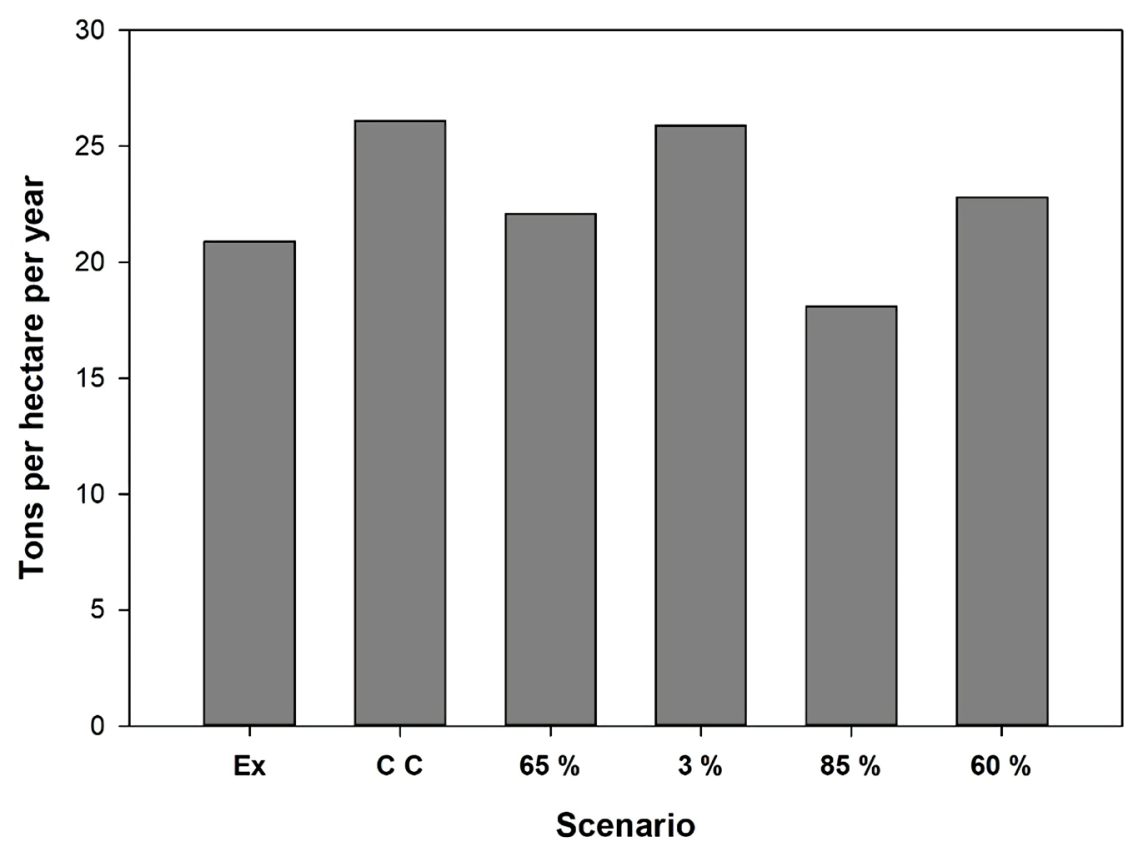

Figure 5. Spatially-explicit estimates of existing erosion integrated for the entire subwatershed of the North River determined by the RUSE model (designated as "Ex", from France et al. [8]), and in response to predicted climate change to the end of the $21^{\text {st }}$ century (designated as " $\mathrm{C} \mathrm{C}$ "), and as mitigated by four management scenarios of $65 \%, 3 \%$, $85 \%$, and $60 \%$ watershed reforestation, corresponding respectively from left to right to Scenarios 1, 2, 3, and 4, as described in the text. Values represent averages from 20 iterative modeling runs, with errors of about \pm 1.2 tons $\cdot \mathrm{ha}^{-1} \cdot \mathrm{yr}^{-1}$, or about $5 \%$ of the means.

for more than a century. Numerous studies have shown that the widespread planting of trees can, by reducing runoff and flow, be used to mitigate the effects of climate change [5], through what can be referred to as "climate-smart reforestation" [6]. The present modeling exercise suggests that implementation of such a strategy for a largely rural watershed in Atlantic Canada, in order to mitigate projected increases in soil erosion resulting from climate change, will necessitate massive increases in the areas that are forested. The long-term viability of food and fibre production on landscapes which might presently be only marginally suited for such activity will have to be reexamined if the preservation of water quality at levels commensurate to today is deemed by society to be of paramount importance.

Our present modeling of the influence of reforestation on soil erosion in the North River subwatershed was based on the iteratively random assignment of the forested category of land-use to upland areas. We know, however, that not all locations in any Atlantic Canadian watershed are equally susceptible to soil erosion and the consequent threat they pose to surface water vulnerability [43]-[48]. The choice for land use managers interested in mitigating the projected effects of climate change will be in determining exactly where to actively replant the rural landscape. Considerable evidence exists that riparian forests are of particular 
importance in protecting Canadian waters [49]-[54]. Should land-use managers therefore preferentially focus on waterside, as opposed to watershed, reforestation? Will such a strategy generate "more bang for the buck" in terms of mitigating climate change increases in soil erosion?

Comparing results between the present modeling exercise for the surface area of the entire North River subwatershed and those from earlier modeling restricted to the riparian zones [8], provides an opportunity to address these queries. Focusing on regional climate change predictions to the end of the century, the present modeling first established a minimum riparian buffer of $30 \mathrm{~m}$ (which subsumed $9 \%$ of the surface area of the subwatershed) to which was then randomly added other amounts of $51 \%, 76 \%$, and $56 \%$ of upland forested a real cover for the respective landscape Scenarios 1,3, and 4. All three of these scenarios were found to reduce soil erosion, but only the best case Scenario 3, in which $85 \%$ of the total area of the watershed was reforested (i.e. $9 \%$ riparian + $76 \%$ upland), generated predictions of soil erosion that were below those of existing conditions (Figure 5). Previous modeling of the same climate change conditions for the same subwatershed [8] found that only by expanding riparian forests to a constant width of $70 \mathrm{~m}$ would elevated levels of erosion through climate change be reduced to levels comparable to the present-day situation, and that such a management strategy would subsume $19 \%$ of the surface area of the subwatershed. So here we have a situation in which a wide riparian forested buffer of $70 \mathrm{~m}$ offers a degree of erosion mitigation that is comparable to a narrow riparian forested buffer of $30 \mathrm{~m}$ to which is added another $76 \%$ of upland forest. Clearly, for this particular subwatershed, a managerial strategy of prioritizing the reforesting of those areas in proximity of $70 \mathrm{~m}$ to streams makes sense in that it would take up far less of the available land in the watershed, thereby allowing for more agriculture and forestry to occur in locations distant from the streams. The present study gives credence to Capron et al.'s [55] contention that riparian zones will become "hotspots" for research and management concerning adaptation to climate change over the next century.

Understanding the interplay between climate and land-use management with respect to ecohydrology and soil erosion is essential for achieving the long-term sustainable management of watersheds [56]. Sometimes, however, this interplay is not straightforward. For example, there is an interesting land-use and climate change story for north-central New England, located in the same bioregion of the present study watersheds in Nova Scotia, and which is therefore also expected to experience increases in rainfall, runoff, and erosion resulting from climate change [57]. Here, in consequence of farm abandonment, there has been widespread natural reforestation since the middle of the nineteenth century [58]. Recently, however, despite the widespread extent of this regional rewilding, changing patterns in large-scale atmospheric circulation, causing a higher severity of rainfall events, have still led to increases in the consequent magnitude of watershed runoff and flows [59] [60] [61] [62] [63]. Other modeling studies from elsewhere have also suggested that climatic effects on ecohydrology can 
easily supersede land-use influences of urbanization and vegetative coverage [64] [65] [66] [67]. As well, changes in rainfall amounts are known in at least one case to have had a greater effect on rates of watershed erosion than a complete removal of forests through either commercial logging or wildfires [68]. In short, all these are examples where the effects of regional climatic changes can trump those attributed to localized land-use management. The lesson for land-use managers in Atlantic Canada is that there will no doubt be limitations to the ultimate degree to which reforestation can be relied upon as a default strategy to counteract the projected effects of climate change.

\section{Acknowledgements}

G. Brewster is thanked for technical assistance in developing the hydrological models, as he and C. Zhang are with respect to the soil erosion model, and also T. O'Brien for providing the land-use maps. This research was funded by an Agriculture and Agri-Food Canada Technical Development Grant.

\section{Conflicts of Interest}

The authors declare no conflicts of interest regarding the publication of this paper.

\section{References}

[1] Stone, B. (2009) Land Use as Climate Change Mitigation. Environmental Science \& Technology, 43, 9052-9056. https://doi.org/10.1021/es902150g

[2] Bastin, J.-F., Finegold, Y., Garcia, C., Mollicone, D., Rezende, M., Routh, D., Zohner, C.M. and Crowther, T.W. (2019) The Global Tree Restoration Potential. Science, 365, 76-79. https://doi.org/10.1126/science.aax0848

[3] Nearing, M.A., Pruski, F.F., and O’Neal, M.R. (2004) Expected Climate Change Impacts on Soil Erosion Rates: A Review. Journal of Soil and Water Conservation, 59, 43-49.

[4] De Munck, C.S., Hutchings, T.R. and Moffat, A.J. (2007) Impacts of Climate Change and Establishing a Vegetation Cover on Water Erosion of Contaminated Spoils for Two Contrasting United Kingdom Regional Climates: A Case Study Approach. Integrated Environmental Assessment and Management, 3, 443-455. https://doi.org/10.1897/IEAM_2008-016.1

[5] Trabucco, A., Zomer, R.J., Bossio, D.A., van Straaten, O. and Verchot, L.V. (2008) Climate Change Mitigation through Afforestation/Reforestation: A Global Analysis of Hydrologic Impacts with Four Case Studies. Agriculture, Ecosystems \& Environment, 126, 81-97. https://doi.org/10.1016/j.agee.2008.01.015

[6] Locatelli, B., Catterall, C.P., Imbach, P., Kumar, C., and others. (2015) Tropical Reforestation and Climate Change: Beyond Carbon. Restoration Ecology, 23, 337-343. https://doi.org/10.1111/rec.12209

[7] Patton, A.S.M. (2005) A Study of the Hydrological Characteristics of the North and Salmon Rivers in Relation to Central Colchester County Flooding. Dalhousie University, Truro, Nova Scotia.

[8] France, R.L., Zhang, C. and Brewster, G.R. (2018) Integrated Modeling of Soil Erosion for a Canadian Watershed in Response to Projected Changes in Climate and 
Consequent Adoption of Mitigating Best Management Practices. Journal of Geoscience and Environmental Protection, 6, 12-34.

https://doi.org/10.4236/gep.2018.66002

[9] Environment Canada (1988) Hydrotechnical Study of Truro and Area Floodplain. Flood Damage Reduction Program. Environment Canada, Ottawa.

[10] El-Sharif, A. and Hansen, D. (2001) Application of SWMM to the Flooding Problem in Truro, Nova Scotia. Canadian Water Resources Journal, 26, 439-459. https://doi.org/10.4296/cwrj2604439

[11] Sterling, S.M., Garroway, K., Guan, Y., Ambrose, S.M. and Horne, P. (2014) A New Watershed Assessment Framework for Nova Scotia: A High-Level, Integrated Approach for Regions without a Dense Network of Monitoring Stations. Journal of Hydrology, 519, 2596-2612. https://doi.org/10.1016/j.jhydrol.2014.07.063

[12] CBCL Consulting Engineers (2017) Flood Risk Study. Joint Flood Advisory Committee County of Colchester, Town of Truro and Millbrook First Nation. https://www.truro.ca/adm/708-Truro-flood-risk-study/file.html

[13] France, R.L. and Aitchison, P.W. (2019) Climate Change Predictions of Increased Watershed Flow in Atlantic Canada: Implications for Surface Water Vulnerability and Ameliorative Land Use Planning and Management. Journal of Geoscience and Environmental Protection. (In Press)

[14] Laprise, R., Caya, D., Giguere, G., Bergeron, H. and Cote, J.P. (1998) Climate and Climate Change in Western Canada as Simulated by the Canadian Regional Climate Model. Atmosphere and Oceans, 36, 119-167. https://doi.org/10.1080/07055900.1998.9649609

[15] Caya, D. and Laprise, R. (1999) A Semi-Implicit Semi-Lagrangian Regional Climate Model: The Canadian RCM. Monthly Weather Review, 127, 341-362. https://doi.org/10.1175/1520-0493(1999)127<0341:ASISLR>2.0.CO;2

[16] Nova Scotia Government (2005) Adapting to a Changing Climate in Nova Scotia: Vulnerability Assessment and Adaptation Options. Final Report. Nova Scotia Government. Halifax.

[17] Madani, A. (2010) Impact of Climate Change on Growing Season Soil Water Deficit and Surplus and on Nitrogen Pollution in Agricultural Watersheds in Nova Scotia. Unpublished Report, Nova Scotia Agricultural College, Nova Scotia.

[18] Webb, K.T., Thompson, R.L., Beke, G.J. and Nowland, J.L. (1991) Soils of Colchester Country, Nova Scotia. Report No. 19, Nova Scotia Soil Survey, Agriculture Canada.

[19] Schwab, G.O., Fangmeier, D.D., Elliot, W.J. and Frevert, R.K. (1993) Soil and Water Conservation Engineering. John Wiley and Sons, New York.

[20] SNSMR (2005) Service Nova Scotia and Municipal Relations. Nova Scotia Watershed Coverage for the North and Salmon Rivers. Government of Nova Scotia.

[21] NSDF (2003) Nova Scotia Department of Forestry Geographical Information System.

[22] NSDNR (2001) Nova Scotia Department of Natural Resources Geographical Information System.

[23] Ponce, V.M. (1989) Engineering Hydrology, Principles and Practices. Prentice-Hall, Upper Saddle River, NJ.

[24] Expert Committee on Soil Survey (1982) The Canada Soil Information System (CanSIS), Manual for Describing Soils in the Field. Canada Committee on Land Resources Services, Ottawa. 
[25] Environment Canada (2003) Weather Office Climate Data.

[26] Renard, K.G., Foster, G.R., Yoder, D.C. and McCool, D.K. (1994) RUSLE Revisited: Status, Questions, Answers, and the Future. Journal of Soil and Water Conservation, 49, 213-220.

[27] Soil and Water Conservation Society (SWCS) (1995) RUSLE User Guide Revised Universal Soil Loss Equation Version 1.04, Ankeny, IA.

[28] Renard, R.G. and Freidmond, J.R. (1994) Using Monthly Precipitation Data to Estimate the R Factor in the Revised USLE. Journal of Hydrology, 157, 287-306. https://doi.org/10.1016/0022-1694(94)90110-4

[29] Wicklund, R.E. and Smith, G.R. (1948) Soil Survey of Colchester County Nova Scotia, Report No. 3. Nova Scotia Soil Survey. Experimental Farms Service, Dominion Department of Agriculture.

[30] Sheeran, M.D. (2000) Comparison of Observed and Calculated Annual Soil Losses for Prince Edward Island Using the Revised Universal Soil Loss Equation. Dalhousie University, Halifax, Nova Scotia.

[31] France, R.L. (2006) Introduction to Watershed Development: Understanding and Managing the Impacts of Sprawl. Rowman and Littlefield, Lanham, MD.

[32] France, R.L. (1995) Macroinvertebrate Standing Crop in Littoral Regions of Allochthonous Detritus Accumulation: Implications for Forest Management. Biological Conservation, 71, 35-39.

[33] France, R.L. (1996) Carbon Isotope Ratios in Logged and Unlogged Boreal Forests: Examination of the Potential for Determining Wildlife Habitat Use. Environmental Management, 20, 249-255. https://doi.org/10.1007/BF01204009

[34] Bosh, J.M. and Hewlett, J.D. (1982) A Review of Catchment Experiments to Determine the Effect of Vegetation Changes on Water Yield and Evapotranspiration. Journal of Hydrology, 55, 3-23. https://doi.org/10.1016/0022-1694(82)90117-2

[35] Jones, J.A. and Grant, G.E. (1996) Peak Flow Responses to Clear-Cutting and Roads in Small and Large Basins, Western Cascades. Water Resources Research, 32, 959-974. https://doi.org/10.1029/95WR03493

[36] France, R.L. (1997) Potential for Soil Erosion from Decreased Litterfall Due to Riparian Clearcutting: Implications for Boreal Forestry and Warm- and Cool-Water Fisheries. Journal of Soil and Water Conservation, 52, 452-455.

[37] France, R., Peters, R. and McCabe, L. (1998) Spatial Relationships among Boreal Riparian Trees, Litterfall and Soil Erosion Potential with Reference to Buffer Strip Management and Coldwater Fisheries. Annals Botani Fennici, 35, 1-9.

[38] Kramer, R.A., Richter, D.D., Pattanayak, S. and Sharma, N.P. (1997) Ecological and Economic Analysis of Watershed Protection in Eastern Madagascar. Journal of Environmental Management, 49, 277-295. https://doi.org/10.1006/jema.1995.0085

[39] Kindervater, A.D. (1977) Flooding Events in Nova Scotia, a Historical Perspective. Environment Canada, Inland Waters Directorate, Atlantic Region, Halifax, Nova Scotia.

[40] Shepard, M.W. (2011) Updating Intensity Duration Frequency Climate Design Values for the Atlantic Provinces. PEI Ministry Environment, Labour and Justice.

[41] Cooley, H. and Gleick, P.H. (2011) Climate-Proofing Transboundary Water Agreements. Hydrological Sciences Journal, 56, 711-718. https://doi.org/10.1080/02626667.2011.576651

[42] Fankhauser, S. and Schmidt-Taub, G. (2011) From Adaptation to Climate-Resilient Development: The Costs of Climate-Proofing the Millennium Development Goals 
in Africa. Climate and Development, 3, 94-113. https://doi.org/10.1080/17565529.2011.582267

[43] Cantwell, M.Y. (2002) The Effect of Spatial Location in Land-Water Interactions: A Comparison of Two Modeling Approaches to Support Watershed Planning (Newfoundland, Canada) In: France, R., Ed., Handbook of Water Sensitive Planning and Design, CRC Press, Boca Raton, FL, 577-599.

[44] Yang, Q., Chow, T.L., Rees, H.W. and Meng, F.R. (2008) Using a GIS and Digital Elevation Model to Assess the Effectiveness of Variable Grade Flow Diversion Terraces for Reducing Soil Erosion in Northwestern New Brunswick. Hydrological Processes.

[45] Yang, Q., Meng, F., Zhao, Z., Chow, T.L., Benoy, G., et al. (2009) Assessing the Impacts of Flow Diversion Terraces on Stream Water and Sediment Yields at a Watershed Level Using SWAT Model. Agriculture, Ecosystems and Environment, 132, 23-31. https://doi.org/10.1016/j.agee.2009.02.012

[46] Ahmad, H.M.N., Sinclair, A., Jamieson, R., Madani, A., Hebb, D., Havard, P. and Yirodoe, E.K. (2011) Modeling Sediment and Nitrogen Export form a Rural Watershed in Eastern Canada Using the Soil and Water Assessment Tool. Journal of Environmental Quality, 40, 1182-1194. https://doi.org/10.2134/jeq2010.0530

[47] Amon-Armah, F., Yirodoe, E.K. Ahmad, H. Hebb, D. Jamieson, R. Burton D. and Madani, A. (2013) Effect of Nutrient Management Planning on Crop Yield, Nitrate Leaching and Sediment Loading in Thomas Brook Watershed. Environmental Management, 52, 1177-1191. https://doi.org/10.1007/s00267-013-0148-Z

[48] France, R.L. and Pardy, G. (2018) Spatially-Explicit, Exposure-Based Assessment of Surface Water Vulnerability Form Land Use Threats for Time-Efficient and Cost-Effective Watershed Development Planning. Journal of Geoscience and Environmental Protection, 6, 35-55. https://doi.org/10.4236/gep.2018.66003

[49] France, R.L. (1997) Marcoinvertebrate Colonization of Woody Debris in Canadian Shield lakes Following Riparian Clearcutting. Conservation Biology, 11, 513-521. https://doi.org/10.1046/j.1523-1739.1997.95289.x

[50] Steedman, R.J. and France, R.L. (2000) Origin and Transport of Aeolian Sediment from New Clearcuts into Boreal Lakes, Northwestern Ontario, Canada. Water, Air \& Soil Pollution, 122, 139-152. https://doi.org/10.1023/A:1005235604087

[51] Lee, P., Smyth, C. and Boutin, S. (2004) Quantitative Review of Riparian Buffer Strip Width Guidelines from Canada and the United States. Journal of Environmental Management, 70, 165-180. https://doi.org/10.1016/j.jenvman.2003.11.009

[52] Creed, I.F., Sass, G.Z., Wolniewicz, M.B. and Devito, K.J. (2008) Incorporating Hydrologic Dynamics into Buffer Strip Design on the Sub-Humid Boreal Plain of Alberta. Forest Ecology \& Management, 256, 1984-1994.

https://doi.org/10.1016/j.foreco.2008.07.021

[53] Stoffyn-Egli, P. and Duinker, P.N. (2013) An Ecological Approach to Riparian-Buffer Definition, and Implications for Timber Harvests in Nova Scotia, Canada. Journal of Sustainable Development, 6, 111-134. https://doi.org/10.5539/jsd.v6n12p111

[54] Vaidya, O.C., Smith, T.P., Fernand, H. and Leek, N.R. (2008) Forestry Best Management Practices: Evaluation of Alternate Streamside Management Zones on Stream Water Quality in Pockwock Lakes and Five Mile Lake Watersheds in Central Nova Scotia, Canada. Environmental Monitoring and Assessment, 137, 1-14. https://doi.org/10.1007/s10661-006-9370-y

[55] Capron, S.J., Chambers, L.E., MacNally, R., Naiman, R.J., Davies, P., et al. (2013) Riparian Ecosystems in the $21^{\text {st }}$ Century: Hotspots for Climate Change Adaptation? 
Ecosystems, 16, 359-381. https://doi.org/10.1007/s10021-013-9656-1

[56] Jones, J.A. (2011) Hydrologic Responses to Climate Change: Considering Geographic Context and Alternative Hypotheses. Hydrological Processes, 25, 1996-2000. https://doi.org/10.1002/hyp.8004

[57] Nearing, M.A. (2001) Potential Changes in Rainfall Erosivity in the U.S. with Climate Change during the $21^{\text {st }}$ Century. Journal of Soil and Water Conservation, 56, 229-232.

[58] Foster, D.R. (1992) Land-Use History (1730-1990) and Vegetation Dynamics in Central New England, USA. Journal of Ecology, 80, 753-771. https://doi.org/10.2307/2260864

[59] Collins, M.J. (2009) Evidence for Changing Flood Risk in New England Since the Late $20^{\text {th }}$ Century. Journal of the American Water Resources Association, 45, 279-290. https://doi.org/10.1111/j.1752-1688.2008.00277.x

[60] Kim, J.-S., Jain, S. and Norton, S.A. (2010) Streamflow Variability and Hydroclimatic Change at the Bear Brook Watershed in Maine (BBWM), USA. Environmental Monitoring and Assessment, 171, 47-58.

https://doi.org/10.1007/s10661-010-1525-1

[61] Douglas, E.M. and Fairbank, C.A. (2011) Is Precipitation in Northern New England Becoming More Extreme? Statistical Analysis of Extreme Rainfall in Massachusetts, New Hampshire and Maine and Updated Estimates of the 100-Year Storm. Journal of Hydrologic Engineering, 16. https://doi.org/10.1061/(ASCE)HE.1943-5584.0000303

[62] Armstrong, W.H., Collins, M.J. and Snyder, N.P. (2014) Hydroclimatic Flood Trends in the Northeastern United States and Linkages with Large-Scale Atmospheric Circulation Patterns. Hydrological Sciences Journal, 59, 1636-1655. https://doi.org/10.1080/02626667.2013.862339

[63] Barrett, K.R. and Salis, W. (2017) Prevalence and Magnitude of Trends in Peak Annual Flow and 5-, 10-, and 20-Year Flows in the Northeastern United States. Journal of Hydrologic Engineering, 22. https://doi.org/10.1061/(ASCE)HE.1943-5584.0001474

[64] Tong, S.T., Yang, H., Chen, H. and Yang, J.Y. (2016) Hydrologic Impacts of Climate Change and Urbanization in the Las Vegas Wash Watershed, Nevada. Journal of Water and Climate, 7, 598-620. https://doi.org/10.2166/wcc.2016.038

[65] Kim, Y.D., Kim, J.M. and Kang, B. (2017) Projection of Runoff and Sediment Yield under Coordinated Climate Change and Urbanization Scenarios in Doam Dam Watershed, Korea. Journal of Water and Climate Change, 8, 235-253. https://doi.org/10.2166/wcc.2016.068

[66] Chandramouli, C.V., Buddaraju, S. and Kaoukis, N. (2018) Finding Land Cover Change Impacts on Low Flow Regimes. Journal of Water and Climate Change, 9, 196-206. https://doi.org/10.2166/wcc.2017.040

[67] Singkran, N., et al. (2015) Influences of Land Use and Climate Changes on Hydrologic System in the Northeastern River Basin of Thailand. Journal of Water and Climate Change, 6, 325-340. https://doi.org/10.2166/wcc.2014.127

[68] Blais, J.M., France, R.L., Kimpe, L.E. and Cornett, R.J. (1998) Climatic Changes in Northwestern Ontario Have Had a Greater Effect on Erosion and Sediment Accumulation than Logging and Fire: Evidence from ${ }^{210} \mathrm{~Pb}$ Chronology in Lake Sediments. Biogeochemistry, 43, 235-252. https://doi.org/10.1023/A:1006065109925 